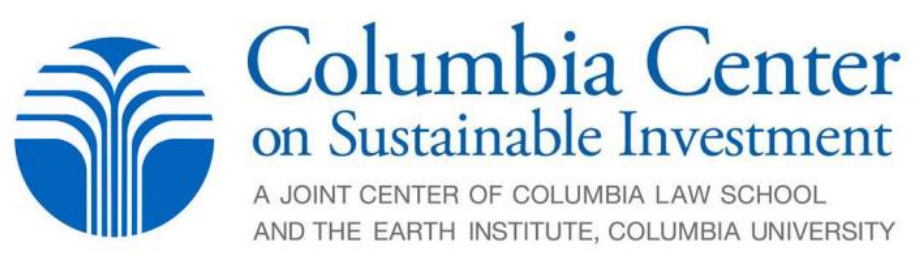

\title{
Preparing Legal Frameworks for Environmental Disasters: Practical Considerations for Host States
}

\author{
Brooke Guven, Perrine Toldano, Lise Johnson
}

February 2020

CCSI Report 


\section{Columbia Center on Sustainable Investment}

The Columbia Center on Sustainable Investment (CCSI), a joint center of Columbia Law School and the Earth Institute at Columbia University, is the only university-based applied research center and forum dedicated to the study, practice and discussion of sustainable international investment.

Its mission is to develop practical approaches for governments, investors, communities and other stakeholders to maximize the benefits of international investment for sustainable development.

Brooke Guven (Legal Researcher), Perrine Toldano (Head: Extractive Industries) and Lise Johnson (Head: Investment Law and Policy) participated in the preparation of this report, and would like to thank Jenny Loutit and Ella Merrill for their contributions. CCSI would also like to acknowledge the significant contributions of several law firms.

**This report was prepared based on research conducted in 2016. Information contained in this report may have been superseded. 


\section{Table of Contents}

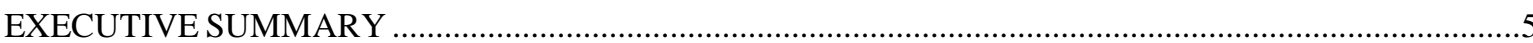



2 SUMMARY OF CASE STUDY COUNTRIES..............................................................................9

3 ISSUES AND BEST PRACTICES IN PROJECT PLANNING, MONITORING AND

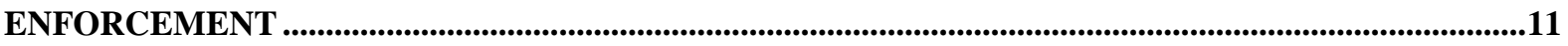

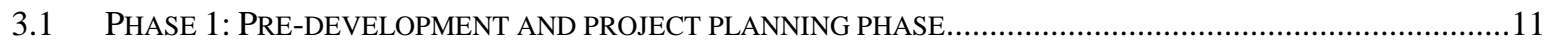

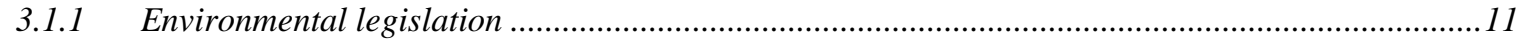

3.1.2 Corporate structure for investments: Suitability of developers ................................................13

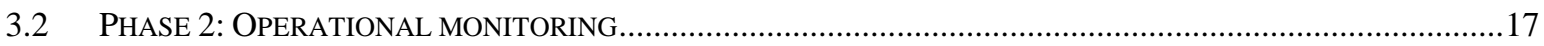

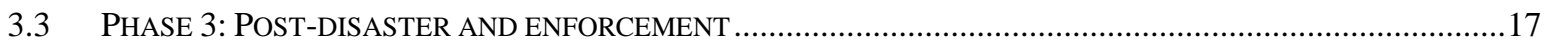

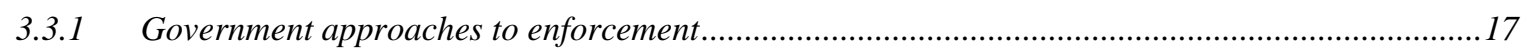

3.3.2 Capacity of governments to deal with environmental disasters.......................................................18

3.3.3 Scope of environmental liability and appropriateness of enforcement rights.................................18

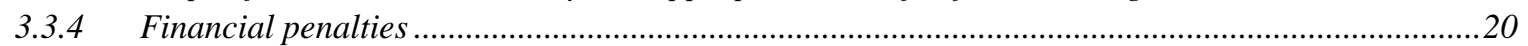

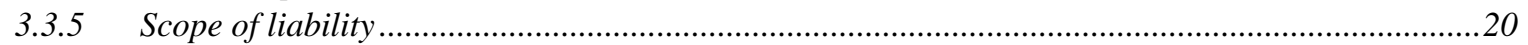

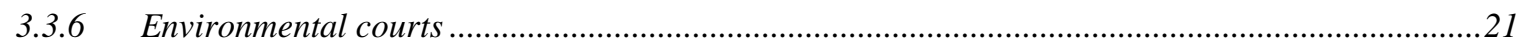

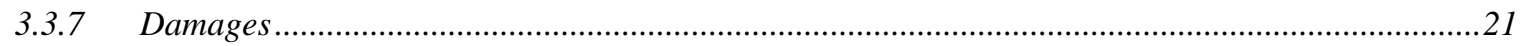

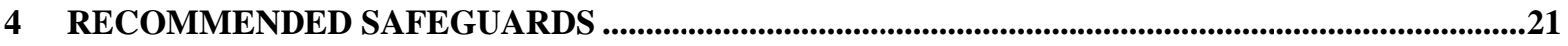

4.1 RECOMMENDATIONS RELATING TO THE PRE-DEVELOPMENT AND PLANNING PHASE .............................22

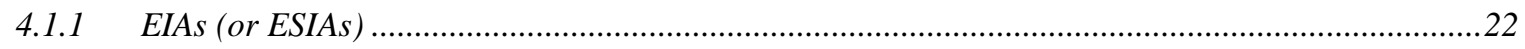

4.1.2 Assessment of developer's experience and technical capability.....................................................22

4.1.3 Assessment of developer's financial capacity ...........................................................................23

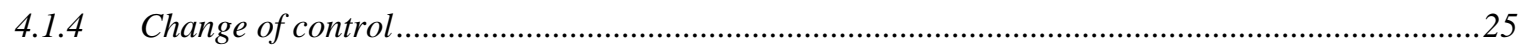

4.1.5 Contractual protections: Incorporation of third party performance standards or foreign legislation

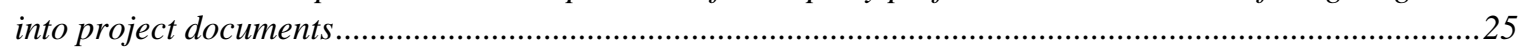

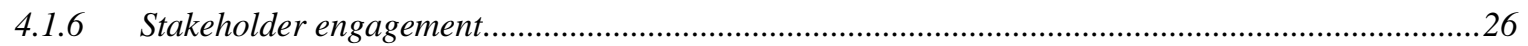

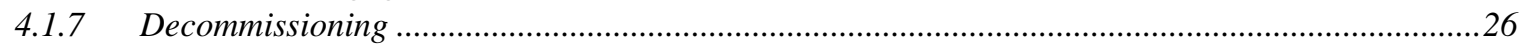

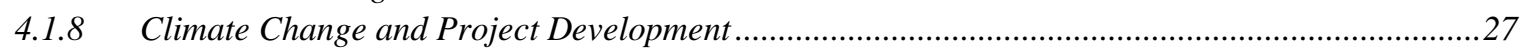

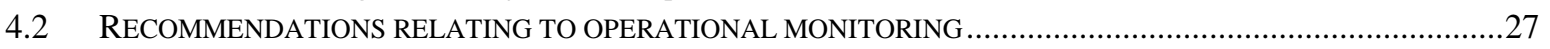

4.3 RECOMMENDATIONS RELATING TO POST-DISASTER AND ENFORCEMENT …........................................28

4.3.1 Extended scope of liability for enforcement actions......................................................................2.

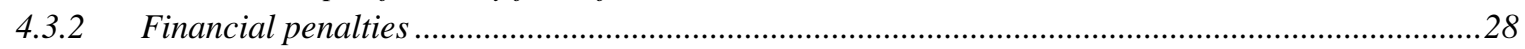

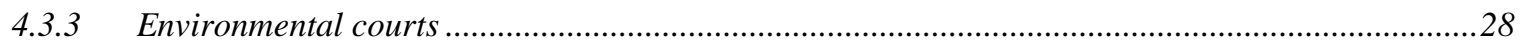

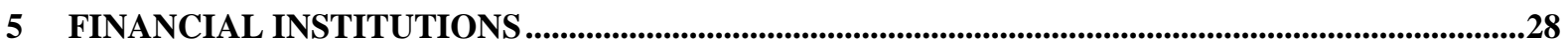

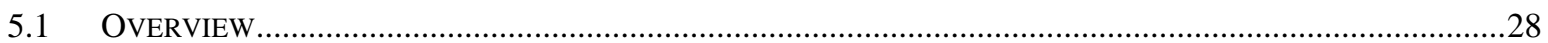

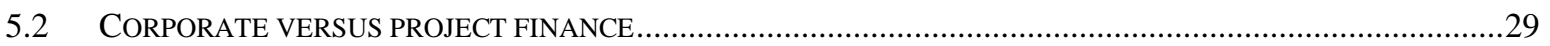

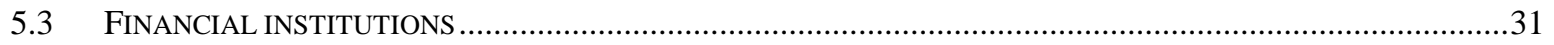

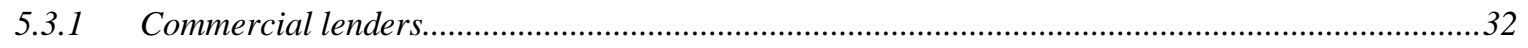

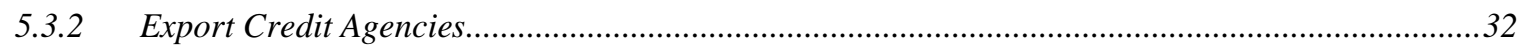



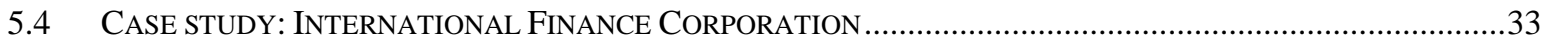

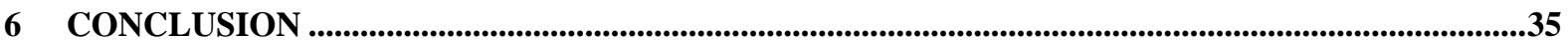

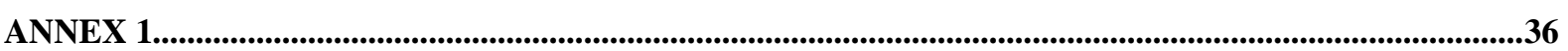

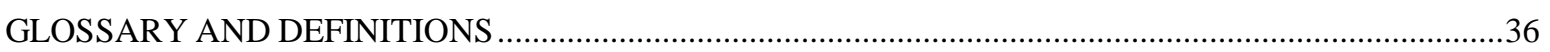

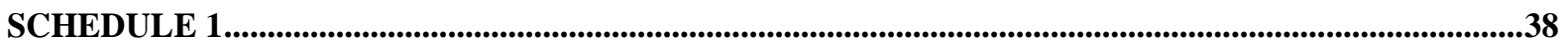

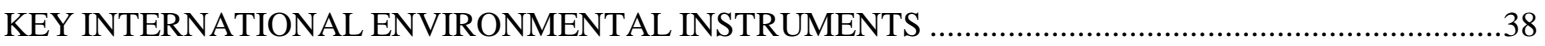


SCHEDULE 2 . 


\section{EXECUTIVE SUMMARY}

By their very nature, extractive industry projects often carry with them a high risk of environmental harm. Governments that host foreign investments in mining or oil and gas projects, in particular, run the risk of such projects encountering environmental disasters or imposing lasting, sometimes irreversible, harm on the environment. Despite the perceived opportunities to accelerate national economic development that such investments bring hostgovernments, the fallout from extractive projects can in some cases outweigh the benefits if host-governments fail to plan for and regulate the execution of these projects.

Nevertheless, host-governments seeking to mitigate the adverse consequences of existing investments and impose greater environmental protections on new investments often face investors that are unwilling to change their operations and update their practices. This Report considers the steps that host-governments can take during each of the pre-investment phase, the operation phase, and, if environmental damage does occur, the enforcement phase, to better protect themselves against environmental disasters associated with private sector investments (particularly those made by foreign investors where all or a large part of the assets of the developer are not located within the host-country). In particular, the report emphasises the role that planning and a robust legal and regulatory framework can have on decreasing the risk of environmentally damaging events and on minimizing the fallout from investment-related environmental disasters.

Using a comparative case study methodology, this report considers the approaches taken by certain governments to domestic environmental legal frameworks and environmental liabilities. We focus on Canada, Chile, Indonesia, Uganda and the United Arab Emirates (UAE) (collectively, the Case Study Countries), which cover Africa, the Middle East, North America, South America and Asia, and represent a wide cross-section in terms of their degree of economic and social development, scope and depth of foreign investment, dominant industries, and strength of public institutions.

The authors set forth various key findings based on analysis of the Case Study Countries.

\section{During the pre-development, negotiation phase:}

- Where there is a lack of applicable environmental legislation in a country, governments should ensure that developers have contractual obligations to comply with best practice, third party performance standards, international environmental law and/or foreign legislation to ensure that developers are held to internationally recognized standards.

- Host governments should ensure that developers are required to submit evidence that they have the necessary technical experience and capability to execute the relevant project as a condition to awarding the project or granting the applicable environmental licence. With respect to projects where there is a significant risk of environmental liabilities, governments should appoint independent technical advisers to assist regulatory authorities in making this determination. 
- Governments should carefully consider whether developers should be required to provide a form (or forms) of financial security for their obligations. Financial security may take the form of a parent company or other guarantee from a creditworthy entity within the developer's group or third party security such as a performance bond or letter of credit that is maintained throughout the operating period.

- Governments should ensure that change of control and anti-assignment provisions are included in environmental licences and applicable project documents so that the government can ensure it has the ability to consent to or be notified of new developers that may join the project.

\section{With respect to Environmental Impact Assessments (EIA):}

- Governments should ensure that an adequate EIA is carried out by the developer as a prerequisite to approving a proposed project or licensee. The EIA should be conducted by a properly qualified, independent third party and should be submitted to and evaluated by the relevant regulatory authority.

- The regulatory authority should actively consult with other stakeholders, including the local community, as part of the process of evaluating the developer's EIA.

- If the regulatory authority approves the relevant licensee or project subject to certain conditions, then a contractual obligation to satisfy such conditions should be included in the project documentation.

\section{During the project operation phase:}

- Regulatory authorities must regularly follow up on EIA conditions to ensure that obligations are carried out by developers and should continue to engage with wider stakeholders to ensure the project continues to meet good environmental practices.

- Governments should consider ring-fencing a part of any revenues, fees or tariffs received from the development of the project in order to fund the monitoring activities of regulatory authorities.

- Governments should seek to provide training to regulatory bodies from third parties such as the World Bank, multilateral agencies, or technical advisers to help advise regulatory authorities about good industry practices, identify unsafe work practices, and ways in which environmental damages can be reduced, mitigated, and/or removed.

\section{During the post-disaster/enforcement phase:}

- The most critical issue identified in the review of the Case Study Countries, particularly with respect to countries that are lower on the economic development scale, is a gap between applicable environmental legislation and the enforcement of such environmental legislation against developers that are in breach of the law. 
- Financial penalties linked to environmental damage and breach of environmental laws and regulations must act as a suitable deterrent. As such, the authors recommend that the quantum of financial penalties have due regard to: (i) the nature of the breach and the consequential socio-economic effect on the environment; and (ii) the amount of the investment made by the developer of the project (such that penalties do not deter smaller investment).

- Environmental laws should seek to "pierce the corporate veil" to hold directors, officers and other responsible persons accountable for breaches committed by the project company. To the extent disclosure and ongoing updating of directors, officers, and other responsible persons can be required by project documentation it may assist to ease enforcement of these kinds of laws.

- Governments may wish to consider establishing specialist environmental courts to focus on environmental disputes in order to aggregate technical expertise and streamline the judicial process. 


\section{INTRODUCTION}

By their very nature, extractive industry projects often carry with them a high risk of environmental harm. Governments that host foreign investments, in particular mining or oil and gas projects, run the risk of such projects encountering environmental disasters or imposing lasting, sometimes irreversible, harm on the environment. Despite the perceived opportunities to accelerate national economic development that such investments bring host-governments, the fallout from extractive projects can in some cases outweigh the benefits if host-governments fail to plan for and regulate the execution of these projects.

Nevertheless, host-governments seeking to mitigate the adverse consequences of existing investments and impose greater environmental protections on new investments often face investors that are unwilling to change their operations and update their practices. This Report considers the steps that governments can take to protect themselves, and by extension the environment and other stakeholder groups, against private sector investments (particularly those made by foreign investors) that carry a risk of causing environmentally damaging events and/or large-scale environmental disasters. In particular, it emphasises the role that planning and a robust legal and regulatory framework can have on decreasing the risk of environmentally damaging events and on minimizing the fallout from investment-related environmental disasters.

Using a comparative case study methodology, this report considers the approaches taken by certain governments with respect to domestic environmental legal frameworks and environmental liabilities. We focus on Canada, Chile, Indonesia, Uganda and the United Arab Emirates (UAE) (collectively, the Case Study Countries). A summary of each Case Study Country and its domestic environmental legal framework is set forth below. These countries cover Africa, the Middle East, North America, South America and Asia, and represent a wide cross-section in terms of their degree of economic and social development, scope and depth of foreign investment, dominant industries, and strength of public institutions.

We selected Canada because of its relatively robust environmental legislation and strict approach to environmental liabilities. For the purposes of this report, Canada generally serves as a benchmark against which to compare and analyse the environmental regimes of the other case-study countries.

Chile, Indonesia, Uganda and the UAE were selected to ensure a spectrum of geographic and economic development. Each of these countries has large reserves of natural resources and a history of investment by foreign investors in the extractive industries, namely: oil and gas (UAE and Indonesia) and mining (Chile and Uganda).

There are three phases of the investment process during which governments can impose environmental protections on extractive industry projects: at the planning or pre-development phase, during the operational phase of the project, and, if environmental damage does occur, during the enforcement phase. This report looks at the issues and best practices arising at each of these phases and suggests some recommended safeguards that governments can implement or impose on investors and projects to strengthen their environmental protection framework and reduce the risk of environmental disasters and project-related environmental damage. 
Of the three phases, the planning/pre-development phase represents the greatest potential for host-governments to minimize project-related environmental harm. This phase covers not only the coordinated planning of the project with the investor but also the imposition of strong legal and regulatory environmental frameworks that establish a system of environmental protection obligations and review requirements. Nevertheless, given that extractive industry projects often operate for many years, it is difficult to plan for all possible outcomes, and so it is also necessary for governments and investors to work together during the operational phase of the project to address potential adverse environmental consequences that may arise. In addition, governments have so far been relatively reluctant to take action against investors whose investments cause environmental damage in the host-state, and so there is room for governments to increase environmental protections through improved enforcement measures. Finally, this report also looks at the role that financial institutions can play in reducing the potential for environmental harm caused by investor projects by imposing conditions on investors linked to the project's financing.

\section{SUMMARY OF CASE STUDY COUNTRIES}

Canada has a robust set of environmental laws and regulations at both federal and provincial levels and a strong regulatory and compliance regime with a history of enforcement action against developers that breach environmental standards. There is a high level of sophistication in the procurement of projects and evaluation of potential developers and appropriate financial security is provided for under Canadian law-governed project documents. The Government of Canada has adopted a strict liability approach to environmental liabilities caused directly or indirectly by developers and their officers and directors.

Chile has established itself as an economic leader in South America. Its national development strategy has been built around its natural resources and in particular the mining sector where it has attracted large-scale foreign investment from blue-chip corporate entities. Since the government of Chile's ratification of the OECD Convention in 2010, Chile has strived to implement best practices in terms of environmental protection and enforcement. As a result, Chile is a good example of a country that has successfully attracted significant foreign investment, while introducing reforms to increase monitoring and enforcement of its environmental legislation.

The UAE has transformed its national economy by attracting investment in the oil and gas sector. The UAE has a relatively advanced environmental regime (particularly in the oil and gas sector) and has benefitted from being able to attract investment from major oil and gas companies. Despite this, it is difficult to evaluate the extent to which the UAE has successfully taken enforcement action against developers that have breached environmental law because of the lack of any publicly available judgments of the UAE courts in this area.

Indonesia has attracted investment from the private sector in its oil and gas and mining industries, but nonetheless faces significant environmental challenges as a result of its large urbanised population, high demand for energy, and exploitation of its available natural resources. Indonesia has a relatively coherent environmental legislative framework that is principally based around command and control regulation requiring developers to carry out an EIA in order to obtain environmental licences. Notwithstanding this, the authors understand 
that in practice Indonesian regulatory authorities have not taken a hard-line approach to the enforcement of environmental laws and regulations.

Uganda is actively encouraging foreign investment into the country including through the use of tax incentives for foreign investors in the mining sector. The government of Uganda has established a framework of environmental legislation that is broadly similar in scope to the other Case Study Countries. However, we understand that there is a gap between the laws and policies as enacted and the practice of implementing environmental conditions and enforcing compliance. 


\section{ISSUES AND BEST PRACTICES IN PROJECT PLANNING, MONITORING AND ENFORCEMENT}

When thinking about environmental protections and the life of an investment project, we can, in broad terms, think of issues as arising in three phases: planning or pre-development (e.g., legislation and contracting), operational (e.g., monitoring and implementation of environmental protections) and, if applicable, post-disaster (e.g., implementing mitigation measures and enforcement of environmental protections). As will be discussed further below, the planning or pre-development phase is in many ways the most critical phase as it is where the parties plan and agree how the operational and enforcement phases will be carried out and thus actions and measures taken at the planning phase have the potential to have the greatest impact on the success of the project and on the ability of the government to mitigate any eventual environmental harm. In general, many host-governments do already have in place certain measures to plan for, prevent and even mitigate the financial, social, and environmental impact of environmental disasters due to or in connection with private investments. Focusing on the five Case Study Countries, this section will explore some of the primary measures and protections that governments use to plan for and deal with environmental disasters and also some of the key issues that arise at each project phase.

\subsection{Phase 1: Pre-development and project planning phase}

The pre-development and project planning phase is likely the most critical phase in the life of an investment project as it sets the stage for the operational and enforcement phases of the project as well as the nature of the relationship of the investment parties. This phase encompasses both legislative and regulatory frameworks that host governments put in place but also the negotiating and contracting phase with the developer. This section looks at the ways in which the Case Study Countries have approached both the legislative and negotiating aspects of the pre-development phase and highlights certain best practices or common practices with respect to the Case Study Countries.

\subsubsection{Environmental legislation}

Each Case Study Country has a legislative framework in place that aims to manage the socioeconomic impact of investment in extractive and infrastructure industries. The level of detail, complexity and overall robustness of these environmental laws varies by jurisdiction. 1

Of the Case Study Countries, Canada has the most extensive set of environmental laws and the strongest track record of enforcement. It is, however, notable that the other countries surveyed in this Report have similar legislation and general legislative requirements in place relating to the approval of projects, licensing regimes and monitoring requirements. For example, each of the Case Study Countries requires developers to carry out an environmental impact

1 Some developing jurisdictions (outside of the Case Study Countries) may have very limited environmental legislation where for example: (i) the economy of the jurisdiction is not reliant on or has undeveloped natural resources; (ii) the jurisdiction has been recently recognized as a sovereign state (e.g. Timor-Leste and South Sudan); or (iii) the jurisdiction is self-autonomous but has not been recognised by the international community (e.g. Somaliland). 
assessment (EIA) as a pre-condition to the award of a project and/or the grant of an environmental licence.

With that being said, the most significant difference between the Case Study Countries is the gap between the applicable environmental legislation, which is broadly similar, and the implementation and enforcement of these measures.

Nonetheless, countries that do not vigorously enforce their environmental laws and regulations may still see investors uphold a certain level of environmentally sound practices in cases when:

- international investors are subject to stringent environmental requirements in their home jurisdictions when those requirements apply to or impact extraterritorial investments and/or

- international investors are required to follow stronger environmental requirements by their lenders (or other parties with a financial interest in the project), in particular where international financial institutions or export credit agencies are involved in the financing of projects, when those institutions require strong environmental requirements to be inserted into the applicable transaction documentation, and when monitoring by such institutions occurs throughout the project.

In general, having a robust environmental legislative and regulatory framework is considered best practice on the part of the host government because it creates a framework from the outset within which the investor must operate and comply and thus reduces the risk of environmental disasters during operation. Leaving the environmental protections to be incorporated on a caseby-case basis in the investment contract leads to inconsistent environmental protection and makes important environmental protection obligations and requirements a negotiated term in investment documentation. Box 1 below includes further discussion on the advantages and disadvantages of legislative and contractual protections. 


\section{Box 1: Legislative vs Contractual Protections}

Environmental protections from foreign investment are generally found in two forms: legislative protections, which are automatically applicable upon investment in a given jurisdiction; and contractual protections, which are intentionally integrated into project documents on a case-by-case basis and applicable only pursuant to the contractual terms.

In countries with weak environmental legislative protections, contractually importing, either by reference or in more detailed format, more robust international (see, for example, Schedule 1 [Key international environmental instruments]) or third-country standards can provide a higher degree of environmental protection and/or investor responsibility than the host country is otherwise able to require based solely on its domestic legislation. However, relying on contractual, rather than legislative, methods to establish environmental protections and standards creates inconsistency in approach and makes it more difficult (and likely, more costly from a financial perspective) for the host government to monitor and enforce the environmental protections once the project is underway. Furthermore, it may also decrease the chance that environmental protections will be incorporated or that any such protections will be sufficiently effective because host government's will be required to negotiate for them (rather than have them automatically applicable in legislative form) and this runs the risk that they may be negotiated away in favor of other project features.

\subsubsection{Corporate structure for investments: Suitability of developers}

Each Case Study Country has in its laws and regulations a mechanism for assessing the suitability of a potential developer, by reference to the developer's technical competence and available financial resources. However, it is not clear how rigorously or with what weight these national legal assessments and requirements are applied in practice when countries are considering proposed investments.

With respect to investments in each Case Study Country it is common practice for developers to incorporate companies as "special purpose vehicles" (SPV) that will legally "hold" the project-level investment. The SPV assets and liabilities will thus be legally remote from the assets and liabilities of the developer, including both the parent company as well as from any other investment projects of the developer. As such, if an environmental disaster occurs at the project level, there remains a risk that the SPV entity may not have sufficient technical experience and financial resources to manage or compensate the host country or other impacted stakeholders for the damage.

The Case Study Countries take different approaches in their project specific documents to reflect the perceived level of risk relating to the performance, or non-performance, as the case may be, by the developer of its obligations. For example, Abu Dhabi's oil and gas concession agreements require each developer to provide a parent company guarantee in relation to its subsidiary's obligations, whereas, similar oil and gas concession agreements in Indonesia do not include this requirement. 
It is notable, however, that UAE law requires project companies incorporated in "onshore" UAE SPVs to be majority owned by UAE entities, which may include ownership by government authorities or state-owned companies. Where a government authority has a direct interest in the SPV entity, the government is able to exercise considerably more control and oversight over the actions and inactions of the SPV and the project.

Ultimately a country's assessment of a developer's suitability to develop a project and the reflection of any risk associated with the developer, including any applicable SPV, in the project documents may also be influenced by:

- market forces, i.e. is the government able to attract significant interest from suitable developers?

- the government's relative bargaining power, i.e. is the government able to dictate terms to the developer?

- political pressure and local interests, i.e. is the government under pressure to procure and complete the relevant project within a particular timeframe?

- planning for decommissioning.

Not all of the Case Study Countries, in particular the UAE and Uganda, have a comprehensive policy and process for decommissioning and do not routinely have funds or financial safeguards in place to cover future liabilities for decommissioning. In addition, with respect to offshore installations (particularly relevant for oil and gas projects), although there are a number of treaties and other international instruments covering the decommissioning of offshore installations, the requirements of these instruments vary considerably and not all Case Study Countries are party to the instruments, as discussed further in Box 2 below.

In Chile, specifically with respect to mining projects, the Chilean Mining Law sets forth specific decommissioning requirements which, among other obligations, require financial guarantees to cover decommissioning expenses. The funds will only be released upon receipt of a "Final Closing Certificate" issued by the Department of Geology and Mining certifying that the project has been closed and all required measures have been implemented according to the mine closure plan.

In Indonesia, oil and gas companies are required by the government to pay into an escrow account to fund abandonment and decommissioning costs. Similarly, mining companies operating in Indonesia are required to either provide a bank guarantee or pay into an escrow account to cover reclamation costs for the environmental damage caused to the land.

In the UAE, the Federal Environment Law (FEL) does not include express provisions regarding decommissioning. There are, however, regulations at an emirate level regarding decommissioning which include, for example, in Abu Dhabi, preparation of a decommissioning plan setting out remediation, site control, and monitoring activities, but the FEL does not include express obligations in relation to financial security for decommissioning obligations. 
Uganda lacks a comprehensive policy regarding decommissioning. Only the PEDP Act provides for a decommissioning plan to be submitted to the Ugandan petroleum authority, which must be done prior to the project company receiving a production licence or specific licence to install and operate the project. 
Box 2: Decommissioning of Offshore Installations: International Legal Obligations

There are a number of treaties, conventions and instruments concerning the decommissioning of offshore installations. These set out primarily the rules to protect against the environmental implications of offshore installations and in particular their abandonment or decommissioning, including liability therefor; however, they do not generally address issues of financial security related to abandonment and decommissioning. The principal international and regional legal instruments and guidelines are summarised in Schedule 2.

As a general matter, international treaties, conventions and instruments are inconsistent in their terms, some requiring complete removal of installations, others requiring partial removal, subject to certain requirements being met (for example, preservation of safety and navigation, protection from pollution and safeguarding marine and fisheries resources). Not all of the Case Study Countries are a party to all or even some of these instruments even when they may be particularly relevant. For example, as a coastal state, the UAE is neither a party to Geneva Convention on the Continental Shelf nor UNCLOS.

Nonetheless, it is generally accepted that a number of provisions of UNCLOS form customary international law. In the context of decommissioning, article 60 of UNCLOS provides that any installations or structures that are abandoned or disused must be removed to ensure safety of navigation, taking into account any generally accepted international standards established in this regard by the competent international organisation, and that such removal must also have due regard to fishing, protection of the marine environment, and the rights and duties of the other states. The competent international organisation is the International Maritime Organization, which has introduced guidelines based on UNCLOS, details of which are set out in in Schedule 2. Subject to certain requirements these guidelines do not require complete removal of installations, although as of January 1998 any installations must be designed and built so that their entire removal is feasible. While the guidelines are by their nature not binding on states' parties, they do represent accepted international practice.

For example, with respect to the UAE oil and gas sector, there is a lack of a tailored legislative and regulatory framework for decommissioning. As a matter of international law, the UAE is bound by its treaty obligations under the Kuwait Protocol, the Kuwait Convention and the London Convention, and as discussed above, UNCLOS to the extent it forms customary international law. The Abu Dhabi Petroleum Conservation Law includes limited obligations in relation to abandonment and decommissioning. Critically, however, issues regarding who has decommissioning liability and, based on such liability, how the financial burden for abandonment and decommissioning will be secured, are unclear and need to be addressed. 


\subsection{Phase 2: Operational monitoring}

Although each of the Case Study Countries has established regulatory bodies which are responsible for monitoring developers to ensure that they comply with environmental legislation and good practices (see Table 1 below [Regulatory Bodies of the Case Study Countries]), it is unclear the extent to which the regulatory bodies (particularly in financiallyconstrained lower income countries) in practice oversee the implementation of environmental safeguards and assess and monitor environmental conditions during the life of applicable projects.

For example, in Uganda, although applicable environmental legislation provides for continuous project monitoring, we understand that the regulatory authority has a shortage of manpower, funding, training and technical expertise, which has led to delays in monitoring compliance with EIA conditions and, when monitoring has been carried out, to sub-optimal levels.

\begin{tabular}{|l|l|}
\hline \multicolumn{2}{|c|}{ Table 1: Environmental Regulatory Bodies in the Case Study Countries } \\
\hline Case Study Country & Environmental Regulatory Body \\
\hline Canada & Environment and Climate Change Canada (ECCC) \\
\hline Chile & $\begin{array}{l}\text { Superintendence of the Environment (Superintendencia del } \\
\text { Medio Ambiente de Chile (SMA)) }\end{array}$ \\
\hline UAE & Environment Agency-Abu Dhabi (EAD) \\
\hline Indonesia & $\begin{array}{l}\text { Ministry for Environment and Forestry and applicable local } \\
\text { AMDAL Evaluation Commission }\end{array}$ \\
\hline Uganda & National Environment Management Authority (NEMA) \\
\hline
\end{tabular}

There appears a strong need to strengthen regulatory bodies in developing countries through the provision of adequate financial resources, human resources (both in terms of manpower and training) and technical support.

\subsection{Phase 3: Post-disaster and enforcement}

Based on the Case Study Countries, set forth below are key findings relating to the ability of governments to deal with a post-disaster scenario including the enforcement rights available to governments against developers that have breached environmental laws.

\subsubsection{Government approaches to enforcement}

Each of the Case Study Countries has enacted legislation that allows the relevant government to bring an action against developers which have breached applicable environmental law. 
In practice, however, implementation and enforcement of environmental laws and regulations may in some cases be lacking. One example of this outside of the Case Study Countries is Nigeria, where there has been considerable environmental damage to the Niger Delta as a result of oil spillages from operations conducted by international developers, but relatively few cases of enforcement against such international developers despite the existence of applicable environmental laws.

The failure to implement and enforce environmental laws in developing countries in particular may be attributed to a number of factors including:

- Budgetary constraints and inadequate financial and administrative resources being available to regulators and industry institutions

- A lack of political will (for various reasons) by a government to enforce its laws;

- An overreliance on permissive environmental legal regimes which permit developers to proceed with a project subject to completion of an EIA or obtaining an environmental license, to the detriment of enforcement and deterrent measures; and

- A desire to meet politically-driven project deadlines.

\subsubsection{Capacity of governments to deal with environmental disasters}

Lower-income Case Study Countries are, as a general matter, less well-prepared to deal with the consequences of environmental disasters as a result of more limited financial resources, a lack of technical experience and expertise, and/or a failure to efficiently coordinate responses from regulatory authorities.

In contrast, Canada, in particular, has a demonstrated capacity and ability to respond swiftly and effectively to environmental disasters. Furthermore, in an effort to assess the origins of the disaster, Canada has also ordered independent reports after an environmental event in order to investigate its causes and to suggest ways in which it could have been prevented.

\subsubsection{Scope of environmental liability and appropriateness of enforcement rights}

We have set out a summary of the Case Study Countries enforcement rights below in Table 2:

\begin{tabular}{|c|c|c|c|c|}
\hline \multicolumn{5}{|c|}{ Table 2: Enforcement } \\
\hline & $\begin{array}{l}\text { Financial } \\
\text { penalties }\end{array}$ & $\begin{array}{l}\text { Prison } \\
\text { sentence }\end{array}$ & $\begin{array}{l}\text { Compliance orders/ } \\
\text { specific performance }\end{array}$ & Other powers \\
\hline Canada & $\begin{array}{l}\text { Criminal and } \\
\text { civil financial } \\
\text { penalties } \\
\text { apply. } \\
\text { Penalties are } \\
\text { increased for }\end{array}$ & $\begin{array}{l}\text { A breach of } \\
\text { environmenta } \\
1 \text { legislation } \\
\text { may lead to } \\
\text { imprisonment } \\
\text {. }\end{array}$ & $\begin{array}{l}\text { Inspectors may issue } \\
\text { orders to stop an illegal } \\
\text { act or require the } \\
\text { developer to carry out } \\
\text { a particular action. }\end{array}$ & $\begin{array}{l}\text { Search and } \\
\text { seizure powers. } \\
\text { Entry into land } \\
\text { without warrant. }\end{array}$ \\
\hline
\end{tabular}




\begin{tabular}{|c|c|c|c|c|}
\hline \multicolumn{5}{|c|}{ Table 2: Enforcement } \\
\hline & $\begin{array}{l}\text { recalcitrant } \\
\text { offences. } \\
\text { Liability may } \\
\text { attach to } \\
\text { officers, } \\
\text { directors, } \\
\text { employees and } \\
\text { agents as } \\
\text { "responsible } \\
\text { persons". }\end{array}$ & & & $\begin{array}{lr}\text { Collection } & \text { of } \\
\text { samples } & \text { and } \\
\text { inspections. } & \end{array}$ \\
\hline Chile & $\begin{array}{l}\text { Financial } \\
\text { penalties } \\
\text { apply, and are } \\
\text { adjusted based } \\
\text { on the size of } \\
\text { the initial } \\
\text { investment and } \\
\text { seriousness of } \\
\text { the offences. }\end{array}$ & $\begin{array}{l}\text { There is no } \\
\text { general } \\
\text { provision for } \\
\text { criminal } \\
\text { environmenta } \\
1 \text { felonies in } \\
\text { Chile. }\end{array}$ & $\begin{array}{l}\text { Environmental courts } \\
\text { may issue compliance } \\
\text { orders and decrees to } \\
\text { require compliance } \\
\text { with environmental } \\
\text { laws. }\end{array}$ & $\begin{array}{l}\text { Individual } \\
\text { citizens can bring } \\
\text { claims against the } \\
\text { Superintendent of } \\
\text { the Environment } \\
\text { in respect of any } \\
\text { perceived } \\
\text { violation } \\
\text { environmental of } \\
\text { rights by a project. }\end{array}$ \\
\hline Indonesia & $\begin{array}{l}\text { Criminal and } \\
\text { civil financial } \\
\text { penalties } \\
\text { apply. }\end{array}$ & $\begin{array}{l}\text { There is no } \\
\text { general } \\
\text { provision for } \\
\text { imprisonment } \\
\text { but criminal } \\
\text { sanctions } \\
\text { may apply. }\end{array}$ & $\begin{array}{l}\text { The Indonesian courts } \\
\text { may make an order for } \\
\text { specific performance. }\end{array}$ & $\begin{array}{l}\text { Individuals or } \\
\text { groups of } \\
\text { individuals may } \\
\text { bring class-action } \\
\text { lawsuits against } \\
\text { developers. }\end{array}$ \\
\hline Uganda & $\begin{array}{l}\text { Criminal and } \\
\text { civil financial } \\
\text { penalties apply } \\
\text { to both } \\
\text { individuals and } \\
\text { corporate } \\
\text { bodies. }\end{array}$ & $\begin{array}{l}\text { Breach of } \\
\text { environmenta } \\
1 \text { legislation } \\
\text { may lead to } \\
\text { imprisonment } \\
\text {. }\end{array}$ & $\begin{array}{l}\text { NEMA has the power } \\
\text { to issue environmental } \\
\text { restoration orders for a } \\
\text { project company to } \\
\text { make good any } \\
\text { damage caused to the } \\
\text { environment. }\end{array}$ & $\begin{array}{l}\text { NEMA has the } \\
\text { power to cancel a } \\
\text { certificate of } \\
\text { approval for a } \\
\text { project. }\end{array}$ \\
\hline UAE & $\begin{array}{l}\text { Potential } \\
\text { substantial } \\
\text { fines: ranging } \\
\text { from } \\
\text { AED1,000 (c. } \\
\text { USD272) to } \\
\text { AED10 }\end{array}$ & $\begin{array}{l}\text { A breach of } \\
\text { environmenta } \\
1 \text { legislation } \\
\text { may lead to } \\
\text { imprisonment } \\
\text { including } \\
\text { life }\end{array}$ & $\begin{array}{l}\text { Requirement under the } \\
\text { environmental laws to } \\
\text { pay all the costs of } \\
\text { treatment or removal } \\
\text { of environmental } \\
\text { damage and the costs } \\
\text { of rehabilitation. }\end{array}$ & $\begin{array}{l}\text { For nuclear } \\
\text { damage, penalty } \\
\text { may include the } \\
\text { death penalty. }\end{array}$ \\
\hline
\end{tabular}




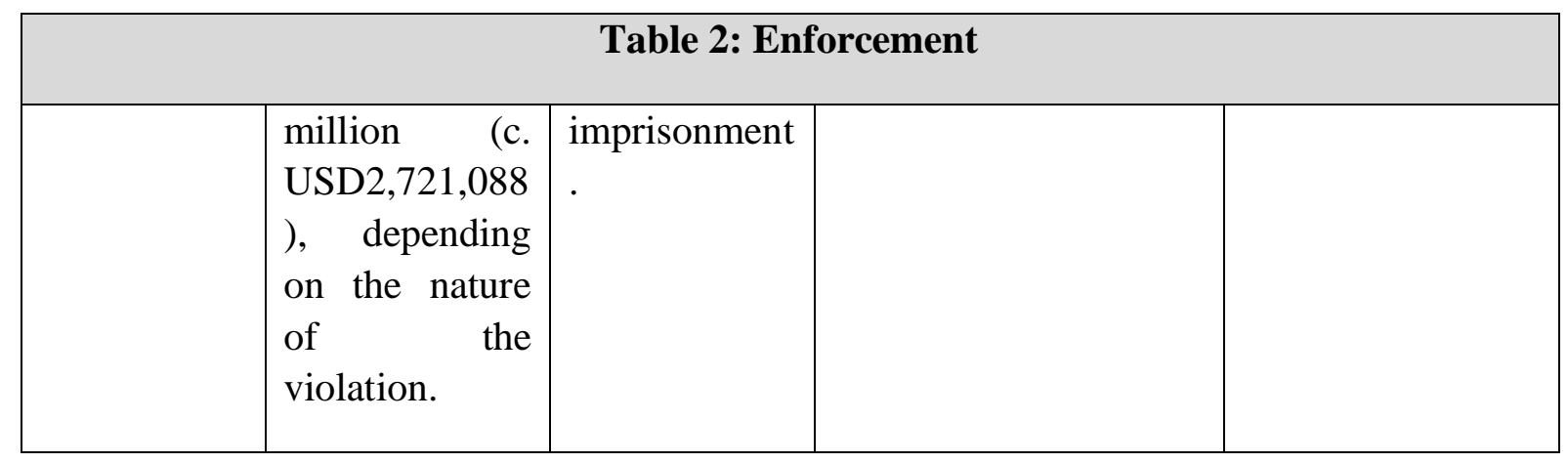

\subsubsection{Financial penalties}

Each of the Case Study Countries allows regulatory authorities to impose financial penalties on developers that are in breach of applicable environmental laws; however, the effectiveness of these penalties varies between the Case Study Countries.

On one end of the spectrum, the financial penalties set out in Uganda's environmental legislation are not particularly onerous for foreign investors, particularly developers from countries with more developed economies and/or strong currencies, as the fines range from approximately US\$558 to US\$5,583,438 (the latter being a one-off fine under the PEDP Act for failure to obtain a licence). As such, even where such financial penalties are rigorously enforced, to the extent that they are not sufficiently large these penalties may not be an effective deterrent for international investors.

In contrast, the environmental law in Chile considers the financial resources of the developer in determining the appropriate penalty for breaching the environmental law. This sliding-scale approach offers two advantages:

(A) by allowing regulators to impost proportionately large fines, developers with extensive financial resources and assets could still potentially be deterred from breaching applicable environmental law as the amount of the fines will be significant and scaled to the financial resources of the developer and not merely to the cost of doing business in the host country; and

(B) the range of fines does not necessarily deter desirable investment by smaller companies or in smaller projects, because the risk is proportionate to the size of the investment.

Notwithstanding this progressive approach to financial penalties, its effectiveness may be somewhat undermined by certain enforcement approaches, including that Chilean courts have been willing to grant significant discounts on fines in exchange for prompt payment by the developer.

\subsubsection{Scope of liability}

Each of the Case Study Countries holds developers directly liable for breaches of environmental law; however, the extent to which this liability also extends to individual 
directors, officers and other connected persons may differ in practice between the Case Study Countries.

In Canada, liability under environmental legislation extends to any "responsible person", including any officer, director or agent of the corporation who directed, authorised, assented to, acquiesced or participated in the commission of the offence. The concept of a "responsible person" may also extend to shareholders, lenders, and other parties, provided that they can be shown to have shaped the actions of the corporation in the commission of the offence. This very deliberate approach of piercing the corporate veil can be contrasted with the environmental law in Uganda, which in theory holds individuals and corporate bodies responsible for breaches of environmental law but it is unclear whether in practice liability would actually extend to an officer, director or agent of a corporate body.

In the majority of the Case Study Countries the state has the burden of proof to demonstrate the requisite level of obligation for environmental contamination. Interestingly, Chile's burden is reversed such that the developer, when accused of breaching environmental obligations, is required to prove that it did not negligently or maliciously cause or contribute to the environmental contamination.

\subsubsection{Environmental courts}

A notable recent development in Chile has been the establishment of specialised environmental courts to focus on resolving environmental disputes. Creating specific environmental courts allows for an aggregation of technical expertise, a forum that can avoid judicial backlog, and streamlining of cases. It is furthermore a strong signal of a host country's commitment to environmental protection. Chile has successfully prosecuted a number of major mining companies for environmental legal violations since the courts were instituted.

\subsubsection{Damages}

In common law jurisdictions the scope of an award for damages as a result of environmental damage may be greater than in civil law jurisdictions because of the way in which common law judges determine loss.

\section{RECOMMENDED SAFEGUARDS}

The Case Study Countries included in this Report cover Africa, the Middle East, North America, South America and Asia, and represent a wide cross-section in terms of the degree of economic and social development, scope and depth of foreign investment, dominant industries and strength of institutions. Extrapolating these five countries to a global discussion of diversity and functionality, there is no 'one size fits all' list of safeguards that will work with respect to the nature of foreign investment in every, or any one, jurisdiction. However, by comparing a variety of strategies across different country contexts, this Report aims to provide context and background to various approaches thus providing a reference for strategies that can be tailored to a particular circumstance. 
Set out below is a summary list of various types of safeguards used in connection with major projects, along with corresponding analysis regarding their strengths, weaknesses, and contextual applicability.

\subsection{Recommendations relating to the pre-development and planning phase}

\subsubsection{EIAs (or ESIAs)}

Environmental Impact Assessments (EIAs) are used as a mechanism to 'pre-vet' a project from an environmental perspective at the pre-development stage, before the relevant government authority gives its consent for the project to proceed.

EIAs provide a significant opportunity for the host country to determine the potential environmental (and, with respect to Environmental and Social Impact Assessments (ESIAs), social) impacts of a project and to set out any conditions upon which the project will be permitted to proceed, which may include on-going monitoring and compliance requirements, financial security, and disaster response plans.

Each of the Case Study Countries requires developers to carry out an EIA as a prerequisite to the development of a project. However, as opposed to the applicable frameworks in Canada and Chile, which have more robust mechanisms for the ongoing monitoring and evaluation of EIA requirements, the three other Case Study Countries (Uganda, the UAE and Indonesia), appear to emphasize to a greater degree initial regulatory approval of the projects and to a lesser degree the ongoing obligations that may be required by the developer. As such, while applicable legislation in these latter countries typically provides for on on-going monitoring and evaluation of projects, we understand that in practice the ongoing EIA-related requirements are often given much less weight than the initial EIA approval at the project inception.

Furthermore, the EIA process in some Case Study Countries is not immune to misaligned incentive structures. For example, in Uganda, project companies are required to hire their own private consultants to conduct an EIA (as opposed to choosing from a government-approved list, in consultation with the government, hiring a consultant of the government's choosing, or the government hiring the consultant). As such, the private consultant may be incentivised to represent the interests of the company that hired it and, by extension, to produce less objective results. Ideally all EIAs will be conducted by independent and unbiased experts. To the extent a host government does not have strong institutions and/or sufficient resources to ensure that the EIA is conducted with such impartiality, such host countries may therefore seek to ensure that at a minimum, consultants are subject to standards of professional liability and are required to maintain professional liability insurance.

\subsubsection{Assessment of developer's experience and technical capability}

It is important that governments assess the suitability of developers for major projects by reference to the developer's relevant experience and technical capability. Although it may not always be possible to prevent environmental disasters from occurring, the appointment of an experienced and technically capable developer will limit the risk of potential environmental disasters occurring and such a developer will be better placed to mitigate the effects of the 
environmental damage when compared to a developer with little or no experience and/or technical capability.

An assessment of technical competence may, for example, require developers to submit evidence that:

- the developer has successfully executed other "similar" projects by reference to factors such as: the size, complexity, and geographic location of the project;

- the developer's proposed technology is "proven" within the industry;

- the developer is and has been able to successfully attract finance for its projects; and

- there are no existing environmental liabilities or claims affecting any of the developer's other projects and the developer has a strong environmental track record in all other jurisdictions.

Where possible, governments should appoint technical advisers (i.e. international and recognized engineering consulting companies) to assist government entities in assessing and evaluating the technical competence of developers.

\subsubsection{Assessment of developer's financial capacity}

At the same time as carrying out an assessment of a developer's technical capability, governments should evaluate whether the contracting entity will have sufficient financial means to meet its contractual obligations and to address any potential environmental liabilities during the entire project life-cycle.

One of the most important considerations for government entities is the identity of the developer entity that will enter into the project agreements. Governments should ensure that they are contracting with a creditworthy entity which is both able to discharge its obligations under the relevant project agreements and able to meet any potential liabilities that may occur during the term of the project, for example as a result of an environmental disaster.

For their part, foreign developers looking to enter an overseas jurisdiction will have various considerations. They will typically look to ensure that:

- profits made from operations in the relevant overseas jurisdiction may be freely repatriated to the developer's holding company or parent company;

- the corporate structure of the developer's investment is structured in such a way as to reduce the company's overall tax liability and benefit from investment treaty protections; and

- the choice of corporate structure is compliant with the local companies law or law on foreign investment; for example, UAE law requires developers to establish a local entity where the project is to be situated in 'onshore' UAE. 
As a result of the considerations above, such developers will typically seek to establish a local SPV entity to act as the contracting entity with host government entities. Developers may also prefer to establish an SPV company where they are looking to raise project finance or similar limited-recourse debt funding (see "Corporate vs Project Finance" below).

In many cases, particularly when a SPV-based, project-finance structure is used, the creditworthiness of the developer's corporate family may not be applicable to the project-level financing and project investment. There is a resulting tension between, on the one hand, a government's preference for contracting with substantial creditworthy corporate entities, which by definition will include a larger portion of the corporate family beyond simply the SPV, and, on the other hand, a developer's preference for contracting with local SPV entities. Careful attention should therefore be given to the financial picture of the particular entity within the context of the project agreements (which may include guarantees, bonds or other sources of revenue in some cases).

Governments should therefore carefully consider whether to request developers to provide security in the form of:

- an up- or cross-stream guarantee from within the corporate family in relation to the performance by the developer's subsidiary of its obligations;

- a letter of credit, performance bond, or payment into an escrow account, to address any particular issues of concern for the government, for example to fund the cost of decommissioning the project facilities at the end of the concession term; and/or

- insurance to address the risk of unanticipated disasters. Outside of political risk insurance, which is available through public agencies (see "Export Credit Agencies" below), insurance to address environmental risks may be available through the private sector. Some countries may require specific domestic licensing/registration requirements of insurers (although in combination with reinsurance, an agency from a larger market may become involved). The scope of insurance may be capped and limited (e.g. does not include wilful misconduct) and pricing of insurance will depend on the particular transaction and risk profile of the project.

While companies may be reluctant to issue up- or cross-stream guarantees because of, among other reasons, disclosure requirements, up- or cross-stream company guarantees, in addition to providing other financial security for the host-government, have other benefits resulting from the additional diligence given to the project within the corporate family of the developer. This is because the internal corporate processes required to grant an up- or cross-stream guarantee will frequently mean that the project is scrutinized at higher levels of the corporate structure than it otherwise may be absent a guarantee requirement. This additional scrutiny can result in greater diligence and risk consideration of the project as a whole, which can have a beneficial impact on environmental controls when;

- the nature of the project is considered to be 'high risk', for example, whether there is a potential risk of large environmental liabilities; 
- the developer is able to demonstrate that it has successfully completed similar projects and has the technical experience and know-how to execute the new project; and

- the developer is a subsidiary of a high-profiel listed corporate entity with considerable resources and stakeholder engagement

Setting aside the monetary value of the guarantee, the certainty on the part of a government of recourse to a more creditworthy entity and the incentive for developers to avoid reputational damage to the group that may arise with an environmental disaster, may themselves be sufficiently useful in practice to avoid the need for enforcement through the courts or dispute resolution.

\subsubsection{Change of control}

In order to ensure that governments retain the benefit of a developer's technical experience and financial resources through the entire life-cycle of a project, we recommend that governments include change of control and anti-assignment provisions in environmental licences and project documents as well as in applicable law.

Change of control and anti-assignment provisions allow governments to assess whether, as a result of a change of corporate control or assignment of the project, there has been a material change in relation to the originally contracted developer's ability to perform its obligations under an environmental licence or project document and, if so, to cancel or terminate the project licence or agreement. These kinds of contractual provisions are important protections in practice to prevent companies with a poor environmental track record from becoming licensees through the acquisition of other companies or other means, and for the government to ensure that it retains some level of control over the entity that is managing an environmentally sensitive project.

4.1.5 Contractual protections: Incorporation of third party performance standards or foreign legislation into project documents

Unlike most developed countries, some developing countries may not have a robust set of environmental laws and regulations that:

- Require developers to act in accordance with standards that are consistent with "good industry practice"; or

- Set out an effective environmental liability regime

One solution that we recommend to address a comparative lack of environmental legislation would be to ensure that developers have contractual obligations in project documents to comply with:

- "good industry practice", which should be defined in further detail or confirmed by a technical adviser appointed to advise the relevant governments; 
- third party performance standards that promote best practices, such as the IFC's Performance Standards or other environmental guidelines which are produced by ECAs such as JBIC or NEXI; and/or

- the laws and/or regulations of a jurisdiction with more robust environmental protections, as if they were directly applicable in the host country.

A breach by a developer of any of these contractual obligations may ultimately result in an event of default (if not remedied by the developer) pursuant to the terms of the project documents, which among other rights given to the government, may allow the government entity to terminate the relevant project document(s).

The authors are aware of a number of projects in which governments and financial institutions have required developers to apply a higher standard of performance to their obligations than may be required under the laws of the jurisdiction in which the project is situated. As an example, a major public-private partnership (PPP) project in the Middle East contractually incorporates specific European environmental legislation into its terms because of the lack of domestic environmental legislation that is specialized to the particular project.

A significant development over the last ten years has been the increased involvement of ECAs and MLAs in setting certain social and environmental performance standards that developers are required to meet in order to obtain financing for projects. As such, governments may benefit from the relevant negotiating positions of these institutions and their environmental requirements for a project. The role that financial institutions can and do play in project planning and monitoring is further discussed below.

\subsubsection{Stakeholder engagement}

Many claims brought against private companies and/or governments of developing countries related to the impacts of environmental damage have been brought by individuals or groups of individuals within a project-affected community.

Governments should require meaningful stakeholder engagement, which at a minimum should be to the extent required by international and domestic laws and norms, with affected communities at the EIA stage of the project and that stakeholders continue to be consulted as part of the on-going monitoring process.

\subsubsection{Decommissioning}

In general countries, and developing countries in particular, should place greater emphasis at the inception of a project on requiring provisions that will address decommissioning and reclamation costs, thereby considering the lifecycle of the project and not merely short-term project revenues. A more holistic and proactive approach will better address the financial and environmental risks that are presented by early decommissioning or abandonment of an extractives project. Comprehensive procedures should be put in place, including requirements for decommissioning and abandonment plans. It is also critical that there is a mechanism provided for assessing future costs and that adequate financial security be provided as a prerequisite to project inception. 


\subsubsection{Climate Change and Project Development}

Climate change impacts on development will differ from country to country. However, it is clear that without proactive measures and the establishment of safeguards, climate change is likely to have a significant negative impact on future developments. Each of the Case Study Countries is a party to the climate change conventions, including the UNFCCC and the Paris Agreement.

At a domestic level in accordance with the UNFCCC, each of the Case Study Countries other than Canada is a Non-Annex 1 country and therefore is not obligated to reduce its emissions. Nonetheless, all the Case Study Countries have the ability, particularly when considering preconditions to foreign investment in their countries, to develop regulations and policies to achieve emissions reductions, depending on their capacity to realise sustainability.

Climate change is currently not typically addressed as a separate risk event in project documents; however, climate change is being directly and indirectly addressed in projects through the following means:

- the enactment of new legislation by governments and ratification of international conventions, such as the Paris Agreement;

- $\quad$ sustainable development policies of governments, such as the UAE's goal to achieve 27 per cent of its energy requirements from clean energy sources by 2021 ;

- selection criteria in a procurement process, which specifies certain technical requirements which may include reducing a developer's carbon footprint;

- contractual obligations in project agreements for developers to comply with, including:

- good industry practice

- third party performance standards, such as IFC's Performance Standards and JBIC's J-MRV Guidelines; and

- $\quad$ project specific key performance indicators; and

- the indirect effects of climate change, e.g. extreme weather conditions, may be treated as a force majeure event under project agreements.

\subsection{Recommendations relating to operational monitoring}

In order to ensure that developers are actually proceeding with a project and acting in accordance with a government-approved EIA, environmental licensing requirements, and best practices, local regulatory authorities should frequently monitor the project and the status of the developer's compliance with its contractual, domestic, and international obligations over the life-cycle of a project. 
In practice, local regulatory authorities may face a number of challenges with this recommendation, including, shortages of manpower, funding, training and technical expertise. As a result, governments may wish to:

- consider ring-fencing part of any revenues, fees or tariffs received by the government from the development of the project, and apply such amounts to fund local regulatory authorities such that they are able to effectively monitor the project and the developer's compliance with its obligations; and

- seek training from third parties such as the World Bank, MLAs or technical advisers to instruct regulatory authorities on good industry practices, identify unsafe work practices, and consider ways in which environmental damage can be reduced, mitigated and removed.

Where a project is financed, another practical safeguard is that project lenders will ensure that designated technical advisers carry out continuous monitoring of the project during the term of the financing agreements. However, absent a contractual information-sharing agreement, governments cannot be assured that they will be informed of nor have any control over this monitoring.

\subsection{Recommendations relating to post-disaster and enforcement}

\subsubsection{Extended scope of liability for enforcement actions}

Countries should adopt new legislation or amend existing environmental legislation to ensure that liability for certain acts or omissions of a developer that cause environment damage may be attached to directors and officers of the developer. Such liability will ensure that, where applicable, such individuals may be held personally liable for offences committed by the developer. Such liability can provide an incentive for the directors and officers to take an active and engaged role in ensuring that key steps are taken toward environmental compliance and protection.

\subsubsection{Financial penalties}

Countries should adopt new legislation or amend existing environmental legislation to ensure that financial penalties for breach of environmental laws are proportionate to the nature of the damage and are appropriately scaled to ensure that such penalties act as a real deterrent to all developers and do not crowd-out small developers or small projects (see Table 2 for details of the financial penalties imposed by the Case Study Countries).

\subsubsection{Environmental courts}

In order to ensure that claims relating to environmental liabilities are efficiently and appropriately addressed, countries should consider establishing specialized courts to determine matters relating to environmental disputes.

\section{FINANCIAL INSTITUTIONS}

\subsection{Overview}


Financial institutions increasingly play an important role in promoting sustainable development and best practice and also in mitigating the risk of environmental disasters. Financial institutions are involved in projects in various roles:

- as lenders, financial institutions will expect to see an appropriate level of risk allocation between the project company and the procuring government entity (including in relation to environmental issues) and can act as powerful stakeholders, potentially influencing some of the decisions taken by the management of the project company during the term of the project;

- as financial advisers to governments, financial institutions may assist in establishing an international benchmark for procurement processes and ensuring environmental compliance, even where the laws of the relevant country do not provide for such safeguards; and

- as high-profile, often publicly listed corporate entities, financial institutions may be incentivised by their large shareholder base to ensure that their investments and their reputation are protected from the reputational and financial damage that occurs when such entities are involved financially or otherwise in large-scale environmental disasters.

\subsection{Corporate versus project finance}

The choice of financing structure by developers of a project has an important bearing on the scope and influence that financial institutions may have on both a particular project and on the borrower (which may differ depending on the lending structure, as detailed in Table 3 below). Financing structures can broadly be divided into 'corporate finance' and 'project finance' and the table below sets out the key features and differences between these structures.

\begin{tabular}{|l|l|l|}
\hline \multicolumn{3}{|c|}{ Table 3: Corporate vs. Project Finance } \\
\hline Issue & Corporate finance & Project finance \\
\hline Borrower & $\begin{array}{l}\text { Creditworthy entity within the } \\
\text { developer's group, typically a } \\
\text { substantial holding or parent } \\
\text { company of the developer but } \\
\text { not the entity actually engaged } \\
\text { in the project. }\end{array}$ & $\begin{array}{l}\text { SPV that has been created by } \\
\text { of the project. The SPV's } \\
\text { assets and liabilities will be } \\
\text { limited to the project's assets } \\
\text { and liabilities and will not } \\
\text { extend to other entities within } \\
\text { the corporate group. }\end{array}$ \\
\hline Tenor of debt & $\begin{array}{l}\text { Shorter tenor. Typically less } \\
\text { than three years with a } \\
\text { revolving credit facility. Loan } \\
\text { documentation not necessarily } \\
\text { specific to project. }\end{array}$ & $\begin{array}{l}\text { Longer tenor. Typically } \\
\text { equivalent to the term of the } \\
\text { project in order to line up } \\
\text { repayment of the loan with }\end{array}$ \\
\hline
\end{tabular}




\begin{tabular}{|c|c|c|}
\hline \multicolumn{3}{|c|}{ Table 3: Corporate vs. Project Finance } \\
\hline Issue & Corporate finance & Project finance \\
\hline & & $\begin{array}{l}\text { project revenues. Debt is } \\
\text { specific to project. }\end{array}$ \\
\hline $\begin{array}{l}\text { Leverage } \\
\text { (debt:equity } \\
\text { ratio) }\end{array}$ & $\begin{array}{l}\text { No leverage. Developer needs } \\
\text { to provide return to } \\
\text { shareholders from use of lines } \\
\text { of credit. }\end{array}$ & $\begin{array}{l}\text { Highly leveraged. Developer } \\
\text { funding is limited to equity } \\
\text { with high proportion of lower } \\
\text { cost long-term debt. }\end{array}$ \\
\hline $\begin{array}{l}\text { Balance sheet } \\
\text { treatment }\end{array}$ & $\begin{array}{l}\text { On balance sheet. Ties up } \\
\text { corporate lines of credit and } \\
\text { may constrain further } \\
\text { borrowing as it adds to overall } \\
\text { leverage. }\end{array}$ & $\begin{array}{l}\text { Potentially off-balance sheet } \\
\text { (depending on accounting } \\
\text { analysis). The only limit on } \\
\text { SPV's borrowing is the lenders' } \\
\text { willingness to lend. }\end{array}$ \\
\hline $\begin{array}{ll}\text { Project due } \\
\text { diligence }\end{array}$ & $\begin{array}{l}\text { Limited project-specific due } \\
\text { diligence. Lenders look to the } \\
\text { creditworthiness of the } \\
\text { borrower entity as a whole to } \\
\text { repay the loan, not to the } \\
\text { creditworthiness of the specific } \\
\text { project. }\end{array}$ & $\begin{array}{l}\text { Extensive project-specific due } \\
\text { diligence, including full } \\
\text { contractual risk analysis and } \\
\text { financial modelling. Lenders } \\
\text { need to be comfortable that the } \\
\text { revenues from the project can } \\
\text { meet the cost of debt service } \\
\text { (i.e. repayment of the principal } \\
\text { amount of the loan plus any } \\
\text { applicable interest). }\end{array}$ \\
\hline Security & $\begin{array}{l}\text { Cross-guarantees from } \\
\text { downstream and upstream } \\
\text { group companies to meet debt } \\
\text { service obligations. }\end{array}$ & $\begin{array}{l}\text { No up- or cross-stream } \\
\text { guarantees for debt service } \\
\text { obligations. }\end{array}$ \\
\hline $\begin{array}{l}\text { Covenants and } \\
\text { undertakings }\end{array}$ & $\begin{array}{l}\text { Limited and/or generic project- } \\
\text { specific corporate covenants } \\
\text { and undertakings to be given by } \\
\text { borrower entity. }\end{array}$ & $\begin{array}{l}\text { Extensive project-specific } \\
\text { covenants and undertakings to } \\
\text { be given by borrower entity } \\
\text { (e.g. compliance with } \\
\text { applicable laws, including } \\
\text { environmental laws). }\end{array}$ \\
\hline $\begin{array}{l}\text { Events of } \\
\text { default }\end{array}$ & $\begin{array}{l}\text { Events of default limited to } \\
\text { corporate defaults } \quad \text { (e.g. } \\
\text { insolvency) }\end{array}$ & $\begin{array}{l}\text { Corporate events of default } \\
\text { and project-specific events of } \\
\text { default, e.g. material breach of } \\
\text { project documents. }\end{array}$ \\
\hline
\end{tabular}

Corporate financings are typically used by large developers such as international oil and gas 
companies, who will often look to fund new investments from the gross profits of the group and will enter into very large revolving capital facilities with a group of lenders in order to give them the financial flexibility to deploy funds within their corporate group where and as necessary to projects undertaken by their subsidiary companies. Here, lenders are typically relying on the creditworthiness of the corporate group as a whole and are less concerned with the specific allocation of the capital within the group or to specific projects (within the parameters established by the financing documents).

Project finance is used as a financing tool in a large number of sectors including the mining, utilities (conventional and renewable power and wastewater), infrastructure (e.g. schools, hospitals, ports, airports), oil and gas and transport industries, and are particularly used in cases where projects are procured on the basis of an open tender. As can be seen from the summary table above, lenders to a project finance transaction are lending based on the creditworthiness of the project as opposed to the creditworthiness of the larger corporate family, and are thus incentivised through the structure of their investment to ensure that project-specific risks, including environmental risks, are appropriately addressed by the borrower, and that specific obligations and liabilities attach to the borrower in both the project documents and the related finance documents in order to limit, as far as possible, any exposure that could impair the borrower (an SPV) in its ability to repay the debt service.

As a result of the way a project finance transaction is structured from a legal perspective, the interests of project finance lenders and the procuring government authority will be aligned in a number of material respects for example:

- creditworthiness of the developer(s) - both the project finance lenders and the procuring governmental authority will need to be comfortable that the developer is able to contribute sufficient equity to the project both at the start of the transaction and, if necessary, throughout the term of the project to address any material issues which may arise, e.g. to pay for any costs relating to an environmental liability; and

- technical experience of the developer(s) - both the project finance lenders and the procuring governmental authority will want to know that the developer(s) has a history of being able to successfully execute projects to a standard that is consistent within the relevant industry in order to avoid operational failures that may lead to environmental disasters.

Typically, lenders will appoint a team of independent advisers (financial, technical and legal) to advise them on specific matters related to a particular project. This advice will then need to be taken into account by the developer and its advisers in its own commercial assessment of the project. As such, the availability of project finance can be seen as adding an extra layer of checks and balances both prior to the point of investment by the developer and during the lifecycle of the project.

\subsection{Financial institutions}

There are a number of different financial institutions that are involved in the project-finance market and it is important to distinguish the role and different philosophies of each financial 
institution in order to understand how a particular institution's involvement may affect the overall structuring of a project as well as the consideration given to environmental issues.

\subsubsection{Commercial lenders}

Commercial lenders are retail or investment banks that make debt financing available to developers through debt or project finance facilities agreements, typically through a syndicate of lenders. For projects in developing markets, the lender group may involve a combination of international as well as local banks.

\subsubsection{Export Credit Agencies}

ECAs are public agencies and entities that provide government-backed loans, guarantees, and insurance to corporations that are based the home country but seek to do business overseas as foreign investors, typically in developing countries and emerging markets.

The main advantages for developers in obtaining loans from one or more ECAs are that:

- ECAs are generally able to offer lower interest rates than commercial lenders; and

- ECAs may provide political risk insurance to protect against certain kinds of political risks faced by developers when they invest in foreign markets (e.g. expropriation, nationality-based discrimination).

The table below sets out some of the most well-known ECAs and their country of origin:

\begin{tabular}{|l|l|}
\hline Country & Name of ECA \\
\hline France & $\begin{array}{l}\text { Compagnie Française d'Assurance pour le Commerce } \\
\text { Extérieur, COFACE }\end{array}$ \\
\hline Germany & Euler Hermes Kreditversicherungs-AG \\
\hline Italy & SACE SpA Servizi Assicurativi del Commercio Estero \\
\hline Japan & Japan Bank for International Cooperation, JBIC \\
\cline { 2 - 2 } & Nippon Export and Investment Insurance, NEXI \\
\hline South Korea & The Export-Import Bank of Korea, K-EXIM \\
\hline United States & Export-Import Bank of the United States, EXIM \\
\hline
\end{tabular}

Some ECAs have taken a proactive approach towards promoting sustainable development, including environmental sustainability. For example, $\mathrm{JBIC}_{2}$ and $\mathrm{NEXI}_{3}$, which are widely

2 http://www.jbic.go.jp/en/efforts/environment/confirm (accessed on 22 February 2017).

3 http://nexi.go.jp/en/environment/social.html (accessed on 22 February 2017). 
recognised as two of the most pro-active ECAs, have separately established and published guidelines on environmental and social considerations, which are taken into account by their respective credit committees when determining whether to fund a project. JBIC has also published guidelines for the measurement, reporting and verification of greenhouse gas emissions (the "J-MRV Guidelines"), which set out a number of best practice methodologies for reducing greenhouse gas emissions across a number of different projects. To the extent these guidelines are incorporated as covenants in the applicable contracts, a breach of the applicable guidelines by a developer that is supported by JBIC or NEXI, as applicable, is treated seriously by these institutions and may ultimately trigger an event of default under the relevant finance documents.

\subsubsection{Multilateral agencies}

MLAs are international bodies that provide development aid or assistance, often to developing countries. Well-known MLAs in the projects sector include: the International Finance Corporation; the European Investment Bank, the European Bank for Reconstruction and Development, the African Development Bank, the Asian Development Bank and the Islamic Development Bank. MLAs often act as financiers for developers in jurisdictions in which it may be otherwise difficult to obtain financing from commercial lenders (for various legal, political, economic, or social reasons). In addition, MLAs also provide assistance to government entities in the procurement of projects (including through viability gap funding necessary for a project to achieve commercially viability and related commercial funding).

\subsection{Case study: International Finance Corporation}

The IFC is part of the World Bank Group and offers advisory, investment, and asset management services to encourage private sector development in developing countries. The IFC works closely with governments to:

- provide structuring advice for PPP projects including in relation to public procurement and risk allocation issues;

- advise on new and/or effective laws and regulations; and

- provide training and guidance to government employees.

One of the core aspects of IFC's advisory work is the implementation of its Sustainability Framework, which codifies IFC's strategic commitment to sustainable development and forms a core part of IFC's approach to risk management. The Sustainability Framework comprises of a set of Performance Standards on Environmental and Social Sustainability 4 ("Performance Standards") and IFC's policy on Environmental and Social Sustainability, which defines IFC's commitments to environmental and social sustainability.

\section{IFC Performance Standards}


The Performance Standards are a set of standards for governments and governmental agencies relating to issues of environmental and social sustainability, which aim to provide guidance on how to identify and assess the impact of environmental risks with a view to avoiding, mitigating and/or managing the effect of such risks on the host government.

In the case of IFC's direct financial investments, the IFC requires developers to apply the Performance Standards to manage environmental and social risks and impacts relating to a project so that development opportunities may be enhanced and compliant with IFC standards. Where the IFC is acting as an adviser to governments, the Performance Standards are often translated into contractual obligations on the developer under the applicable concession or project documents.

In no small part due to IFC's leverage as a stakeholder and its ability to ensure that the IFC Performance Standards are incorporated into the legal documentation governing the financing and operation of a project, the Performance Standards are significant in that they allow governments to adopt an environmental regime, and one that reflects good industry practice, even where the legal regime of the host jurisdiction does not have a robust and/or specific set of laws and regulations.

There are eight Performance Standards, however, for the purposes of this Report, Performance Standards 1 and 3 are of particular interest and are considered in further detail below.

Performance Standard 1: Assessment and Management of Environmental and Social Risks and Impacts

Performance standard 1 relates to:

- the carrying out of an integrated assessment to identify the environmental and social impacts, risks and opportunities of projects;

- effective community engagement through disclosure of project-related information and consultation with local communities on matters that directly affect them; and

- management of environmental and social performance throughout the life of the project.

For the purposes of ensuring Performance Standard 1 is enforced, the IFC encourages the use of environmental and social management systems ("ESMS"). An ESMS is a dynamic and continuous process initiated and supported by project management. It involves engagement between governments, workers, project-affected communities and, where appropriate, other stakeholders.

Performance Standard 1 identifies as objectives:

- to identify and evaluate environmental and social risks and impacts of the project. 
- to adopt a mitigation hierarchy to anticipate and avoid, or where avoidance is not possible, minimize, and, where residual impacts remain, compensate/offset for risks and impacts to workers, affected communities, and the environment.

- to promote improved environmental and social performance of clients through the effective use of management systems.

- to ensure that grievances from affected communities and external communications from other stakeholders are responded to and managed appropriately.

- to promote and provide means for adequate engagement with affected communities throughout the project cycle on issues that could potentially affect them and to ensure that relevant environmental and social information is disclosed and disseminated

\section{Performance Standard 3: Resource Efficiency and Pollution Prevention}

Performance Standard 3 relates to reducing levels of pollution in the air, water and land that may have adverse effects on the environment at the local, regional and global levels, and identifies the following objectives:

- to avoid or minimise adverse impacts on human health and the environment by avoiding or minimizing pollution from project activities;

- to promote more sustainable use of resources, including energy and water; and

- to reduce project-related greenhouse gas emissions.

\section{CONCLUSION}

This report has considered key phases of the investment process, pre-development, operational, and enforcement, in which host governments can take proactive steps to prepare for any potential environmental disaster caused by the project developer. Upon a comparative review of the five Case Study Countries, various practices have been identified and discussed. The authors found that the most critical issue impacting the ability of host governments to hold developers responsible for environmental harm is a gap between applicable environmental legislation and the enforcement of such environmental legislation. The authors provided various recommendations (summarized in the Executive Summary) and emphasize the role that planning and a robust legal and regulatory framework can have on decreasing the risk of causing environmentally damaging events and minimizing the fallout from investment-related environmental disasters. 


\section{GLOSSARY AND DEFINITIONS}

Unless defined below, capitalised terms in this Report have the meaning given in the relevant document reported on in this Report.

"Abu Dhabi

Petroleum

Conservation

Law"

"AED"

"Basel

Convention"

"CAD"

"Case Study

Countries"

"CCSI"

"Convention to

Combat

Desertification"

"ECA"

"EIA"

"ESMS"

"IFC"

"IMO"

"IMO Guidelines" means the IMO Guidelines 1989.

"JBIC"

"J-MRV

Guidelines"

"Kuwait

Convention" resources in Abu Dhabi. Particularly in Africa, 1994.

means export credit agency. study. found. of section 2 of this Report. means Abu Dhabi Law No. 8 of 1978 on the preservation of petroleum

means UAE dirhams, the lawful currency of the UAE.

means the Basel Convention on the Control of Transboundary Movements of Hazardous Wastes and their Disposal, 1989.

means Canadian dollars, the lawful currency of the Canada.

means Canada, Chile, Indonesia, Uganda and the UAE, and "Case Study Country" shall mean any one of them as the context so requires.

means the Columbia Center on Sustainable Investment.

means the United Nations Convention to Combat Desertification in those Countries Experiencing Serious Drought and/or Desertification,

means environmental impact assessment or environmental impact

has the meaning given in paragraph 0 of section 2 of this Report.

means International Finance Corporation.

means International Maritime Organisation.

means Japan Bank for International Cooperation.

has the meaning given in paragraph Error! Reference source not

means the Kuwait regional convention for co-operation on the protection of the marine environment from pollution 1978 (and its associated Protocols). 


\footnotetext{
"Kyoto Protocol" means the Kyoto Protocol to the UNFCCC, 1997.

"London

Convention"

"MLA"

"Montreal

Protocol"

"NEMA"

"NEXI"

"OECD"

"OECD

Convection"

"OSPAR

Convention"

"Paris

Agreement"

"PEDP Act"

"Performance

Standards"

"PPP"

"Report"

"SPV"

"UAE"

"UNCLOS"

"UNFCCC"

"USD"

means Convention on the Prevention of Marine Pollution by Dumping of Wastes and Other Matter, 1972.

means multilateral agencies.

means the Montreal Protocol on Substances that Deplete the Ozone Layer, 1987.

means the National Environmental Management Authority of Uganda.

means Nippon Export and Investment Insurance.

means Organisation for Economic Co-operation and Development.

means the Convention on the Organisation for Economic Cooperation and Development, 1960.

means the Convention for the Protection of the Marine Environment of the North-East Atlantic 1992.

means the Paris Agreement, 2015

means the Petroleum (Exploration, Development and Production) Act No. 3 of 2013, Uganda, as defined in section 3.1 of this Report.

has the meaning given in paragraph 5.4 of section 2 of this Report.

means public-private partnership.

means this report entitled Investment for Sustainable Development Report.

means special purpose vehicle.

means the United Arab Emirates.

means the United Nations Convention on the Law of the Sea 1982.

means the United Nations Framework Convention on Climate Change, 1992.

means United States dollars, the lawful currency of the United States of America.
} 


\section{SCHEDULE 1}

\section{KEY INTERNATIONAL ENVIRONMENTAL INSTRUMENTS}

The table below highlights only some of the key international environmental interests which relate to the subject of this Report. It is not an exhaustive list. A comprehensive review of international environmental law is outside the scope of this Report.

\begin{tabular}{|c|c|c|}
\hline Instrument & Key requirements & Status/comment \\
\hline
\end{tabular}




\begin{tabular}{|c|c|c|}
\hline Instrument & Key requirements & Status/comment \\
\hline $\begin{array}{lr}\text { United } & \text { Nations } \\
\text { Framework Convention on } \\
\text { Climate } \\
(\text { UNFCCC) }\end{array}$ & $\begin{array}{l}\text { The Convention aims to stabilise greenhouse gas concentrations "at } \\
\text { a level that would prevent dangerous anthropogenic (human induced) } \\
\text { interference with the climate system." }\end{array}$ & $\begin{array}{l}\text { Entered into force: } 21 \text { Mar } 1994 \\
\text { Signatories: 165. Parties: } 197 . \\
\text { All Case Study Countries are a party: }\end{array}$ \\
\hline
\end{tabular}




\begin{tabular}{|c|c|c|}
\hline Instrument & Key requirements & Status/comment \\
\hline $\begin{array}{l}\text { Convention to Combat } \\
\text { Desertification }\end{array}$ & $\begin{array}{l}\text { The Convention provides a platform to combat desertification and } \\
\text { mitigate the effects of drought through national action programmes } \\
\text { that incorporate long-term strategies supported by international } \\
\text { cooperation and partnership arrangements. }\end{array}$ & $\begin{array}{l}\text { Entered into force: } 26 \text { Dec } 1996 \\
\text { Signatories: 114. Parties: } 196 \\
\text { All Case Study Countries are a party: } \\
\text { - } \quad \text { Canada: acceded (21 Dec 2016) } \\
\text { - } \quad \text { Chile: ratified (11 Nov 1997) } \\
\text { - Indonesia: ratified (31 Aug 1998) } \\
\text { - Uganda: ratified (25 Jun 1997) } \\
\text { - UAE: acceded (21 Oct 1998) }\end{array}$ \\
\hline
\end{tabular}




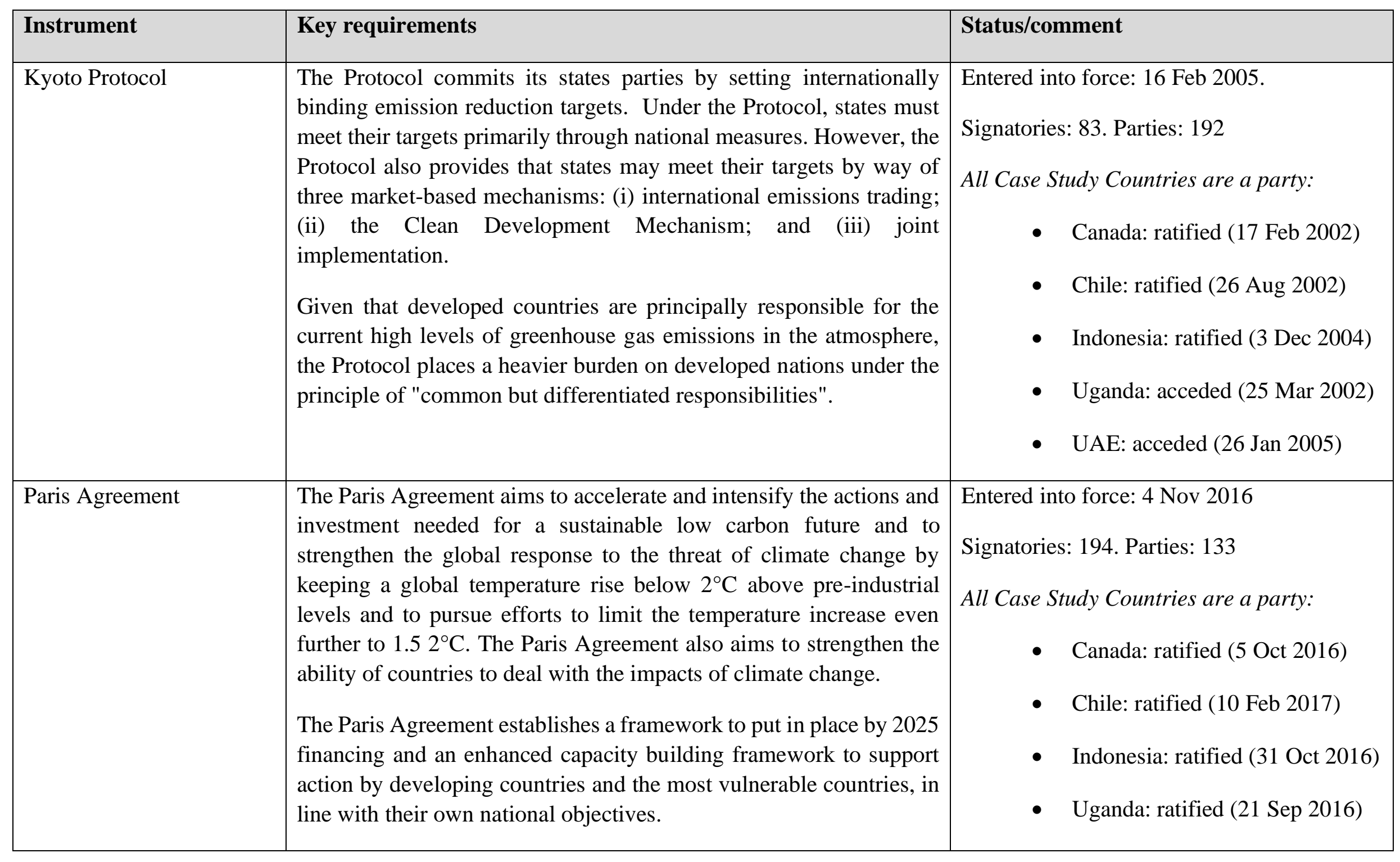




\begin{tabular}{|l|l|c|}
\hline Instrument & Key requirements & Status/comment \\
\hline & $\begin{array}{l}\text { The Paris Agreement requires all states parties to put forward their } \\
\text { best efforts through 'nationally determined contributions' (NDCs) and } \\
\text { to strengthen these efforts in the years ahead. This includes } \\
\text { requirements that all states parties report regularly on their emissions } \\
\text { and on their implementation efforts. }\end{array}$ & $\bullet$ UAE: acceded (21 Sep 2016) \\
\hline
\end{tabular}




\section{SCHEDULE 2}

\section{OFFSHORE DECOMMISSIONING - INTERNATIONAL REGIME}

The principal international legal instruments and guidelines are set out below.

\begin{tabular}{|c|c|c|}
\hline Instrument & Key requirements & Status/comment \\
\hline $\begin{array}{l}\text { Geneva Convention on the } \\
\text { Continental Shelf, } 1958\end{array}$ & $\begin{array}{l}\text { The Convention requires the complete removal of oil and gas } \\
\text { structures which have been abandoned or are no longer being used. } \\
\text { Article 5(1) provides that the exploration of the continental shelf and } \\
\text { the exploitation of its natural resources must not result in any } \\
\text { unjustifiable interference with navigation, fishing or the conservation } \\
\text { of the resources of the sea. } \\
\text { Article 5(2) provides that the coastal state is entitled to construct and } \\
\text { maintain or operate on the continental shelf installations and other } \\
\text { devices necessary for its exploration and the exploitation of its natural } \\
\text { resources. } \\
\text { Article 5(5) provides that any installations which are to be abandoned } \\
\text { or disused must be entirely removed. }\end{array}$ & $\begin{array}{l}\text { Entered into force: } 10 \text { June } 1964 \\
\text { Signatories: 43. Parties: } 58 \\
\text { Of the Case Study Countries, only Canada } \\
\text { and Uganda are a party: } \\
\text { - Canada: ratified (6 Feb 1970) } \\
\text { - Chile: signed, not ratified (31 Oct } \\
\text { 1958)* } \\
\text { - Indonesia: signed, not ratified (8 } \\
\text { May 1958)* } \\
\text { - Uganda: acceded (14 Sep 1964) } \\
\text { - UAE: n/a* } \\
\text { * There is low possibility that article 5(5) } \\
\text { may be customary international law. }\end{array}$ \\
\hline
\end{tabular}




\begin{tabular}{|c|c|c|}
\hline Instrument & Key requirements & Status/comment \\
\hline $\begin{array}{l}\text { Kuwait Convention and } \\
\text { Kuwait Protocol }\end{array}$ & $\begin{array}{l}\text { Article XIII of the Kuwait Protocol provides that each Contracting } \\
\text { State must ensure that the Competent Authority has the power to } \\
\text { require the operator of an offshore installation in the case of platforms } \\
\text { and other sea-bed apparatus and structures, to remove the installation } \\
\text { in whole or in part to ensure the safety of navigation and the interests } \\
\text { of fishing. Each Contracting State must also take all practicable } \\
\text { measures to ensure that the operator has sufficient resources to } \\
\text { guarantee that any such requirements can be met. } \\
\text { Contracting States must pass, and take all practicable steps to enforce, } \\
\text { measures to ensure that no offshore installation which in use has } \\
\text { floated at or near the sea-surface, and no equipment from an offshore } \\
\text { installation, will be deposited on the seabed of the continental shelf } \\
\text { when it is no longer needed. }\end{array}$ & $\begin{array}{l}\text { The Kuwait Convention entered into force on } \\
1 \text { July } 1979 \text { and the Kuwait Protocol entered } \\
\text { into force on } 17 \text { February } 1990 \text {. } \\
\text { According to the UN Environment } \\
\text { Programme database, the UAE has both } \\
\text { signed and ratified the Kuwait Convention } \\
\text { and the Kuwait Protocol: } \\
\text { - the Kuwait Convention was signed on } 24 \\
\text { April } 1978 \text { and ratified on } 1 \text { December } 1979 \text {; } \\
\text { and } \\
\text { - the Kuwait Protocol was signed on } 29 \\
\text { March } 1989 \text { and ratified on } 17 \text { April } 1990 . \\
\text { The Kuwait Convention and Kuwait Protocol } \\
\text { are regional instruments limited to the six } \\
\text { Gulf Cooperation Council states (including } \\
\text { the UAE), Iran and Iraq. }\end{array}$ \\
\hline UNCLOS & $\begin{array}{l}\text { Article } 60(3) \text { provides: Any installations or structures which are } \\
\text { abandoned or disused shall be removed to ensure safety of } \\
\text { navigation, taking into account any generally accepted international } \\
\text { standards established in this regard by the competent international }\end{array}$ & $\begin{array}{l}\text { Entered into force on } 16 \text { Nov } 1994 . \\
\text { Signatories: } 157 . \text { Parties: } 168 .\end{array}$ \\
\hline
\end{tabular}




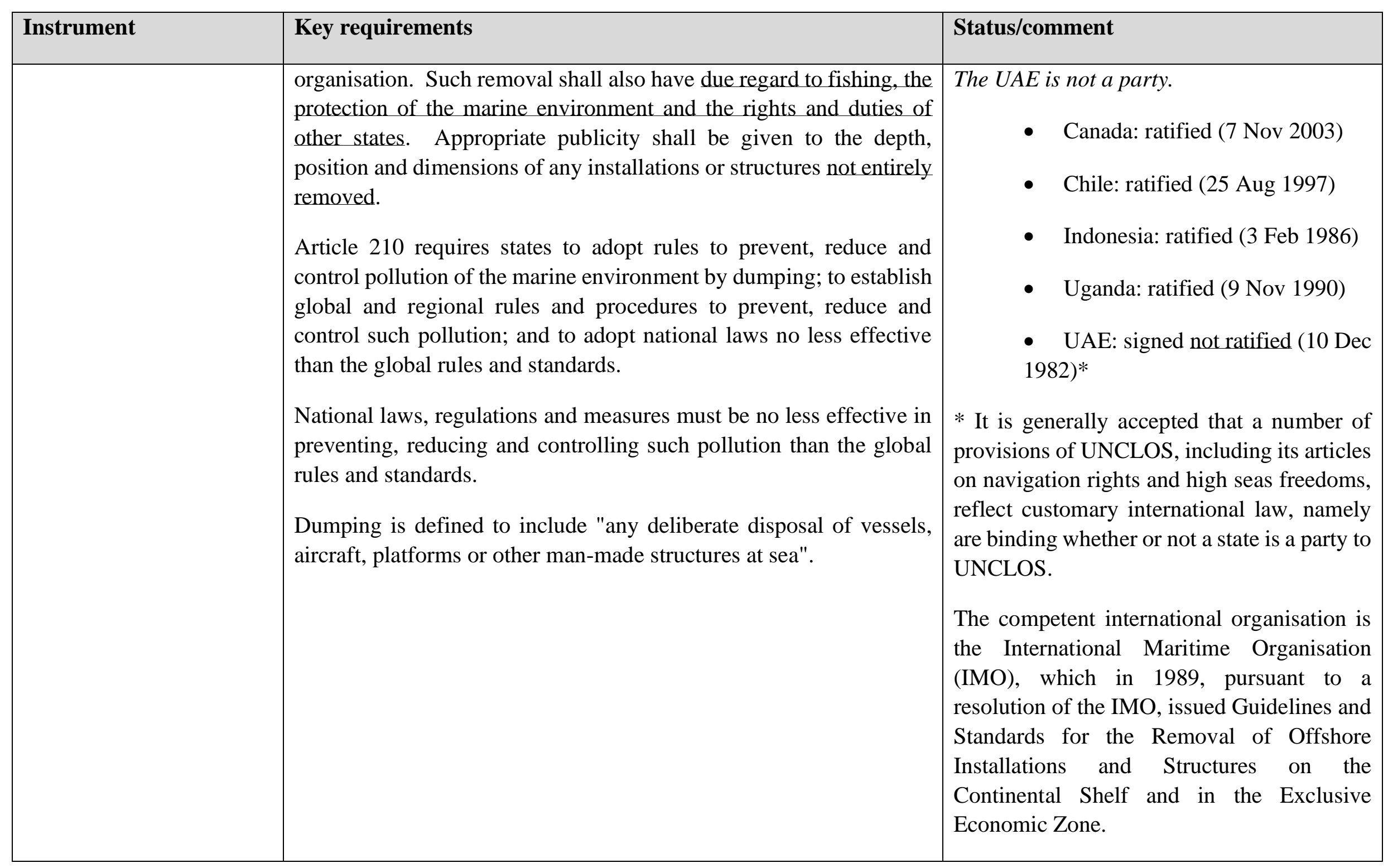




\begin{tabular}{|c|c|c|}
\hline Instrument & Key requirements & Status/comment \\
\hline
\end{tabular}

http://www.imo.org/en/OurWork/Environment/LCLP/Documents/Parties\%20to\%20the\%20London\%20Convention\%20and\%20Protocol\%20 Dec\%202016.pdf 


\begin{tabular}{|c|c|c|}
\hline Instrument & Key requirements & Status/comment \\
\hline OSPAR Convention & $\begin{array}{l}\text { The OSPAR Convention is intended to complement the existing } \\
\text { international treaties. } \\
\text { The OSPAR Decision } 98 / 3 \text { on the Disposal of Disused Offshore } \\
\text { Installations provides that the dumping, and the leaving wholly or } \\
\text { partly in place, of disused offshore installations within the maritime } \\
\text { area is prohibited (paragraph 2), subject to possible derogations } \\
\text { where the competent authority of the relevant Contracting Party is } \\
\text { satisfied that an assessment shows that there are significant reasons }\end{array}$ & $\begin{array}{l}\text { The OSPAR Convention relates to the North } \\
\text { East Atlantic only. However, it provides an } \\
\text { example of international practice, albeit } \\
\text { limited to the North East Atlantic. }\end{array}$ \\
\hline
\end{tabular}




\begin{tabular}{|l|l|l|}
\hline Instrument & Key requirements & Status/comment \\
\hline & $\begin{array}{l}\text { why an alternative (specified) disposal method is preferable to reuse } \\
\text { or recycling or final disposal on land. }\end{array}$ & \\
\hline
\end{tabular}

